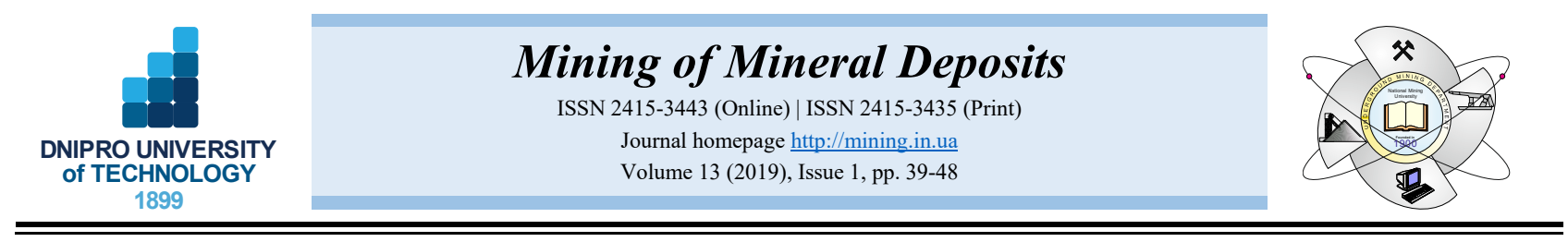

UDC 622.831 .3

https://doi.org/10.33271/mining13.01.039

\title{
FINITE ELEMENT METHOD APPLIED IN MINE PRESSURE COMPUTATION WITHIN THE CONTEXT OF ROCK MASSIF - SUPPORT SYSTEM INTERACTION
}

\author{
M. Toderaş ${ }^{1}$, R. Moraru ${ }^{*}$, C. Danciu ${ }^{1}$ \\ ${ }^{1}$ University of Petrosani, Petrosani, Romania \\ *Corresponding author: e-mail roland moraru@yahoo.com, tel. +40723624105, fax: +40254543491
}

\begin{abstract}
Purpose. The analysis of the current underground mine workings, both those that are in operation and works located within the mining perimeters where activity was stopped, is leading directly to the problem of stability, i.e. safety. The aim of the paper is the stability analysis of underground workings located in strongly metamorphosed andesite and determination of mine pressure in the context of rock - support system interaction was made based on numerical methods, taking into account the effects of inhomogeneous stresses, anisotropy of rocks, and time.

Methods. Numerical - based finite element method was applied to obtain the stress variation radial displacement and mine pressure epures for the analyzed mine workings. To assess the stability of underground mine workings, a mathematical model was developed based on the principle of proper conformity and safety level, according to the main factors that influence the stability of underground workings.

Findings. The results obtained showed that underground workings analyzed are characterized by a low stability level, which is consistent with the results obtained by the observations and numerical method. Depending on the computed level of safety has been established correspondence to class stability of underground mine workings. The results are confirmed by in situ observations and solutions obtained by experiments.
\end{abstract}

Originality. The patterns of the stress-strain state change in the context of rock - support system interaction for horizontal galleries located in strongly metamorphosed andesite.

Practical implications. The research results will facilitate to improve stability of mine workings and to significantly increase the safety level throughout their entire life - cycle.

Keywords: stability, mine pressure, support system, finite element method, conformity level, safety

\section{INTRODUCTION}

Referring to the underground horizontal workings and making an analysis of their location, it comes obvious that they have achieved considerable depths which often exceed $800-1000 \mathrm{~m}$; as mine workings involving important investment, most of them are representing longterm structures with a significant life cycle. Since their design stage, it has become imperative to achieve resistant underground constructions which are reliable, durable and economical. To achieve this goal, and to obtain technically optimal outcomes, there should be well understood the theoretical phenomena and hypothetical assumptions that may underpin the design and execution of the underground workings, simultaneously with a proper understanding and familiarity with the probabilistic concept of construction assurance, thus replacing the anachronistic concept of deterministic calculation, i.e. a design without calculation, based on experience, empirical rules and intuitive application of the laws of mechanics, as actually were and still are encountered in quite a frequently situations met in mine practice.

Starting precisely from these statements, it appears as imperative the requirement of observation in time, based on which it can be made an analysis of underground workings, depending on factors contributing to the stability of the horizontal mine workings. To be able to achieve a situation analysis in which the underground workings in terms of knowledge of intensity and pressure particularity, character of deformation and movement of rocks on the contour, inter-dependence between the moisture degree of rocks and the deformation magnitude, but also to consider the influence these parameters on support systems, direct observations and measurements should be performed on the whole network of underground workings.

(C) 2019. M. Toderaş, R. Moraru, C. Danciu. Published by the Dnipro University of Technology on behalf of Mining of Mineral Deposits.

This is an Open Access article distributed under the terms of the Creative Commons Attribution License (http://creativecommons.org/licenses/by/4.0/),

which permits unrestricted reuse, distribution, and reproduction in any medium, provided the original work is properly cited. 
Over time, the authors have made various studies and research (Toderaş, 2014; Toderaş, Moraru, \& PopescuStelea, 2015; Toderas \& Danciu, 2017) on the horizontal underground mining stability developed in various geomining conditions. From these studies, there are approached a category of workings that have particular interest since they developed in rocks with very special characteristics compared to rocks where were placed other main horizontal workings in different mining perimeters studied previously.

On the occasion of achieving observations it was found that the analyzed horizontal mine workings were driven in the following profiles: simple gallery built, cross section $4.6 \mathrm{~m}^{2}$ (GSZ - $4.6 \mathrm{~m}^{2}$ ) with closed floor; double walled gallery, cross section $9.7 \mathrm{~m}^{2}$ (GDZ $9.7 \mathrm{~m}^{2}$ ) with closed floor; simple concrete supported gallery with open unsupported floor; simple metal elements supported gallery with open floor (GSM $\left.-4.2 \mathrm{~m}^{2}\right)$; shotcrete double gallery, supported on very small length in shotcrete.

With respect to the geological conditions in which they were executed the underground works, important factor on which the stability of any underground construction relies, it was found that these works are placed in the rocks characterized by complex geological conditions, with altered rock, low resistance, water, inflow, advanced cracks and tectonics (micro-tectonics) (Toderas $\&$ Danciu, 2017). Most of these rocks are of andesitic type with different deterioration degrees and consequently, with different content of clay minerals.

More the degree of alteration is advanced more the rock is less resistant and thus pose a major problem in terms of underground workings stability (Brady \& Brown, 1985; Lemaitre \& Chaboche, 1988; Baud, Zhu, \& Wong, 2000; Masuda, 2001; Todera \& Danciu, 2017).

It is a fact that the stability of the working should be examined and assessed based on the working's profile, depending on the concentration of stresses occurring on the contour profile. From this point of view regarding horizontal underground works studied it was found that they were used arched profiles with straight sides, vaulted profiles with curved walls, and trapezoidal and rectangular profiles for transversal workings.

Analyzing the situation of the studied underground horizontal workings, it was found that one of the factors that contributed to the unsatisfactory state of their stability was a weak correlation of the working profile with the geo-mechanical conditions in which these constructions are located.

On the other hand, workings with straight walls, vaulted ceilings and open unsupported floors were typically placed in rocks with high tendency of deterioration and swelling of floor. Given that it was found that the rocks do have a pronounced swelling tendency of floors it should have been adopted horseshoe - type profiles with supported floor and/or circular profiles.

Regarding the state of employed support systems, it can be specified a general finding for the assembly of studied workings, i.e. the support systems deformations have common features embodied by (Toderas \& Danciu, 2017): release into the opening of the side walls; destruction of links between bricks; formation of longitudinal cracks in the walls; detachment as plate-shaped from the walls or the vaults; intense swelling of floor, as a consequence of the water - rock interaction, resulting in deformation of the floors which in some places led to dislevelment reaching a maximum of $1 \mathrm{~m}$ above the normal floor level with destructive effect on the support base, thus causing and horizontally displacements towards the inner gallery, unbalancing the support system.

Meanwhile, in addition to these visual observations there were made measurements of convergence that have extended over a period of approximately four years and allowed us to appreciate the state of underground workings also by their convergence. Thus, the overall reduction in the underground section of these workings comprised a part of the movements caused on the vertical and lateral side walls, due to their movements.

Underground workings contour deformation values have exceeded $20 \%$, sometimes reaching up to $100 \%$ of the baseline profile, the direction of maximum displacement of the contour manifesting the from walls and floor, leading to the conclusion that the workings status is unsatisfactory. Given the character, intensity and direction of strains manifestation and the types of supporting systems considered, it comes that between the two parameters rock - support there is not a rational congruence, so the state of galleries can be generally characterized as unsatisfactory in terms of stability.

\section{GENERAL CONTEXT OF THE RESEARCH}

If in a rock massif is bored an underground working, the labile massif's balance is disturbed, the stress state around the working is fundamentally changed, and the distribution of the tensions to a new equilibrium create concentrations of stress, a phenomenon that leads to the formation of fissures, cracks, deformation on the perimeter of the work; they develop over time and create partial separations, landslides or large masses rock slides which tend to destroy the working.

Digging and supporting any underground working requires from the outset a problem that apparently seems simple, but it turns out to be very complex, namely: how big is the safety of an underground supported or supported space and what is the criterion of choice of support system for these underground workings to prevent their destruction, cause of rock massif's imbalance?

It is this imbalance manifested around underground workings that could not be fully explained, so that today there are still some differences of opinion on the active mining pressure, the use of underground works statics and how to determine this pressure. In the study of mining pressure regime manifestation on horizontal underground mine workings were outlined three basic directions of research: analytical, laboratory and in situ directions, which are overlapping and interdependent (Toderaş, 2014). Authors' opinion is that the current state of knowledge of the mining pressure regime manifestation around underground workings is tributary to the analytic research path, especially in this stage, when the mathematical computation possibilities in technology and industry began to be increasingly more and more used in the determination of the stresses - deformation state, rock displacement and underground construction stress. 
Analytical research includes a large number of assumptions, widely scattered, relating to the manifestation and determination of mining pressure and it is this diversity we explain by their inability to embrace and highlight simultaneously the whole range of factors favoring mine pressure regime manifestation. This also results from the fact that each hypothesis has been made taking into account a single factor or group of factors that were of some importance in specific individual cases and therefore, such a hypothesis is valid only for the conditions in which it was created (Obert \& Duvall, 1967; Brady \& Brown, 1985; Toderaş, 2014; Todera \& Danciu, 2017).

Mining pressure science development was not linear or sequential and nor the alternate of hypotheses so consecutive; however, it is unacceptable for developed hypotheses to be examined now just as a chain of scientific research rejected in time. They signed up in our current representation on rocks with support interaction, like particular cases of such mutual actions; at that time, each hypothesis given and represented an overall regularity.

By developing other ideas (Fomychov, Pochepov, Fomychova, \& Lapko, 2017; De Kerckhove \& Rollier, 2003; Todera \& Danciu, 2017) and taking into account not only qualitatively but also quantitatively the phenomenon of rock - support interaction it was found at the present stage a tendency to leave the path of assumptions and crossing the path of creating mathematical models of more accurately reproduction of the complex solid rock support system with its inherent anisotropies, heterotropies and full range of mechanical, elastic and rheological properties of the massif and support system (Stolle, 1989; Stan-Kłeczek \& Idziak, 2008; Toderaş, 2014; Toderaş, Moraru, \& Popescu-Stelea, 2015; Toderas \& Moraru, 2017). For the analysis of rock massif interaction with the support, as model is used the mechanical model (design scheme and calculation of interaction) whose mathematical analysis determines the quantity and quality of interaction parameters for each case. We mention that to get accurate results, which do not involve the idealization of the massif, the massif's anisotropy should be considered as in principle the problem for anisotropic media differs from setting the problem for isotropic media.

\section{METHOD FOR ANALYZING THE PRESSURE REGIME AND UNDERGROUND WORKINGS STABILITY}

From the mathematical point of view, the problem of determining optimal values is to minimize or maximize some functions are that are subjected to restrictions imposed by the nature of the processes taken into account on the basis of a particular performance; they are gene-rally nonlinear problems. From the existing methods of calculation, the significant development was recorded by the numerical digital processes, in particular the finite element method.

Among the numerical methods that are most suitable for stability analysis of underground workings and mining pressure determination in the context of interaction, it was considered that the finite element method shows me the major advantage of its particularly simple and clear meaning of the fundamental functions. The problem of stability of an underground cavity, respectively the safe and proper sizing of the support system for underground mining, or geotechnical constructions (tunnels, adduction galleries etc.) requires a fair assessment of the developed state of tension, the phenomenon of movement of the massif- support system, the effect of the heterogeneity of these stresses, but also the influence generated by the anisotropy factor, the non-homogeneity and the time.

The fact that the results obtained using the finite element method are real and that the process has been wellchosen, is confirmed both by in-situ observations (Clough, 1965; Blake, 1966; Stolle, 1989; Stan-Kłeczek \& Idziak, 2008; Fomychov, Pochepov, Fomychova, \& Lapko, 2017; Todera \& Danciu, 2017) and the solutions obtained by experimentation (Goodman, Taylor, Clough, Wilson, Zienkiewicz, Reyes, Deere, Anderson and Dodd etc.). Numerical simulation was performed in a custom software, developed by authors in $\mathrm{C}++$ programming language, divided into four blocks: a text - type interface block; an assembly block which comprises the equations used by the finite element method; the specific conditions of each studied problem; a solving block, in which the equations corresponding to mechanical models of interaction have been defined; a postprocessing block for storing results. Model variables are recovered in Gauss class points, which is an analysis "pointer" containing the mechanical object, the latter being a combination of behavioral patterns or laws. In this part of the program is performed the implementation of certain laws of behavior and appropriate criteria.

The problem of determining the stress-strain around different sections of underground mine workings with different profiles which were included in the study (Fig. 1) was solved by the finite element method in terms of two-dimensional and non-linear aspect.

(a)

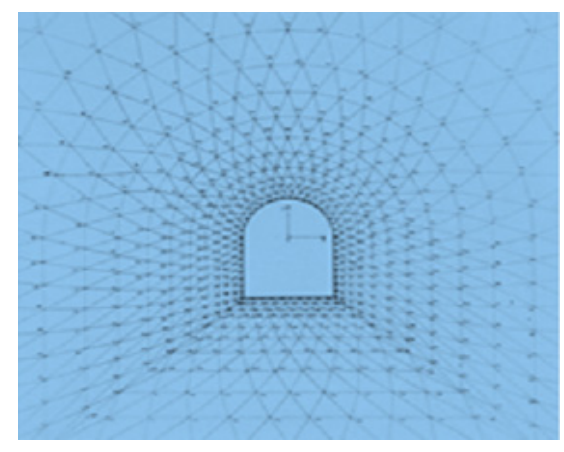

(b)

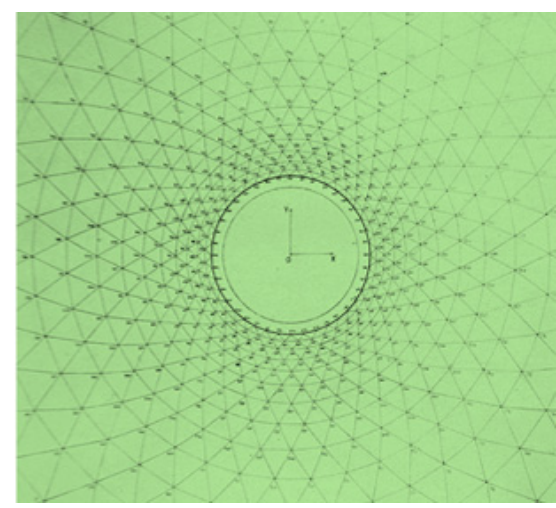

Figure 1. The studied continuum - rock massif - for a mine working with straight walls and vaulted roof (a) and circular shape (b) 
The studied continuum, represented by the rock massif comprising strongly metamorphosed andesite was meshed up in a network of triangular elements corresponding to physical meaning to be modelled.

In our case, given the existing hypotheses to explain the distribution and expression of tensions around mine workings, the size of triangular elements increases as we move away from the working and their number decreeses, a solution that is consistent with the validity of the principle that "as we move away from the mine working (up to $6-8$ times the radius of the working) the value of stresses drops, tending to the tension value met the intact, undisturbed massif'.

Each element is characterized both by mathematical quantities, and by geological, physical-mechanical, elastic deformation and rheological characteristics, according to the properties of the rocks in which the underground workings are drilled, elements finally defining the entire structure. Time was considered in default, by movements that were considered as functions of time.

Knowing the physical and mechanical, elastic and deformation properties of strongly metamorphosed hydrothermal andesite (Toderaş, 2014; Toderaş \& Moraru, 2017), we assume that the state of deformation - stress immediately after digging horizontal mine workings can be characterized to some certain ultra low tension level only by elastic deformations.

With the execution of underground work, the massif gradually transforms into a state of secondary stress-strain characterized by the occurrence of non-elastic deformation elastic-plastic type, and finally the massif to be destroyed, in which case only show such large plastic deformations. This non-linearity is explained by the irreversible structural changes due to redistribution of the tensions, the technological process of realization of the work, the underground environment, hydro-geology conditions. If this development is not prevented in time, then the effect will be decreased resistance of rocks around horizontal mine workings under load time and will yield to massif breakage with destruction of the mine working.

Knowing the tension state in the elastic field and further applying the finite element method, we attempted to introduce also the physical nature of this nonlinearity, the range of stability being limited at the value at which the tension-deformation reaches the plastic domain, until which the rock massif along with the support - system are acting as an elastic-plastic deformation mechanical model.

In this respect, we accepted as criterion the Coulomb-Mohr hypothesis generalized by Drucker-Pragher in accordance with the Reyes assumptions (Reyes \& Deer, 1966; Richter, 1968); this hypothesis or criterion is that the work of the additional strain is 0 . This postulate by Drucker is called "the assumption of normality and stability". Still using this postulate and considering the results, we mention that he finds the scope of the subject in the interactions appropriate that the product of additional vector and of deformation vector is greater than zero and therefore we could call him "postulate of stability and interaction". But this postulate can be used as plastic limit only if it binds to the plastic domain through the plastic potential, finally obtaining the associative law of flow.
To calculate the pressure acting on horizontal mine workings in order to properly dimensioning of the support system, we accepted the concept of interaction rock supporting system, first proposed by Fritz Mohr in 1952. Attention has focused in particular on modifications over time of stresses and rocks studied were those with plastic behaviour.

The reasoning is that in the initial state the assumed mining excavation work will be loaded by the pressure or tension as a result of the massif's natural stress state. For the mine working to be stable, it is required that the action of the rock extracted from the working to be replaced from a static point of view by reaction forces equal in value to the amount of tensions which will act from inside toward outside the working, in which case there are no movements of contour.

This means that the support system with required reaction must be fitted before extracting rock excavated, assumption that resembles with pushing a metal or solid concrete tube into the massif. In practice, the support can not be mounted either before or at the initial time $(t=0)$ to achieve the excavation. The surrounding rock will be subjected to a deformation and it will be developed a new state of tension and thus significant pressure that depend primarily on the nature of the terrain.

Given the nature of the andesitic rock type in which the elastic deformation is fast, the support can not be mounted only in the next phase, i.e. at a time $t>0$, the phase in which around the mine working is developed a zone of non-elastic deformation, which until a certain a radius develops an internal pressure, decreasing the variable parameter, which depends on the pressure of the stress-strain condition, that is to say on the massif's displacements.

In the range of non-elastic deformations there is a time $t_{i}<t_{p l}$ ( $t_{p l}$ is the time to stabilize the elastic nondeformations) corresponding to the radial displacement of rocks on the contour corresponding - in turn - to a state of tension - deformation and thus to an adequate pressure regime to mount a rational support system, providing the mining work stability is ensured during the entire operation.

With the overcoming of such movements, surrounding rock loses its strength, reaching a moment $\left(t_{p l}\right)$ to lose completely its cohesion, in which case the pressure will increase again due to the action deployed by the own weight of the rocks.

Therefore, it is very important that the support mounted after the occurrence of such a relaxation to be of rigid type and not neutral, and the cooperation solid massif - support will be balanced to a certain pressure value and an overall bias that includes radial movement of the rocks on the contour of the work support and movement to the fitting of support system - rock.

Based on these considerations it was performed the analytical formulation for the determination of the pressure and hence the support system's reaction for the given situation, formulation which was carried out through a matrix calculation simulating the reality established by means of the finite element. The problem has been solved for a monolithic support (bricks, concrete).

For simplicity, in the considered continuum elements were numbered from the outside, this logic allowing us 
conventional network division into two parts: massif and support and also allowed to use for the same structure of the various forms of supporting - systems for maintaining unchanged the initial information.

The supporting system profile has been divided into a finite number of elements, starting from the structure's final node number $(N)$ and ending at $(N+n)$; the tips of the support on its outer contour corresponds to the unsupported mine working and therefore their coordinates are consistent with those of the massif.
The problem was analyzed taking into account the rheological behaviour of andesites, settling in this respect the deformation and relaxation velocities of rocks on the contour of mine workings.

Knowing the relaxation velocity and the relaxation time, it was determined the average displacement needed for the creation of the non-elastic deformation area, where the pressure regime is favorable for mounting a supporting system, values which are in the range obtained by the finite element method (Table 1).

Table 1. The relaxation rate and the rock's displacement value on the mine workings contour

\begin{tabular}{|c|c|c|c|c|c|}
\hline Type of working & Location depth, m & $\begin{array}{l}\text { Maximum radial } \\
\text { tension, } \mathrm{daN} / \mathrm{cm}^{2}\end{array}$ & $\begin{array}{l}\text { Relaxation } \\
\text { rate, } \mathrm{cm} / \text { day }\end{array}$ & $\begin{array}{c}\text { Minimum } \\
\text { displacement, } \mathrm{cm}\end{array}$ & $\begin{array}{c}\text { Average } \\
\text { displacement } \\
\text { value, } \mathrm{cm}\end{array}$ \\
\hline \multirow{2}{*}{$\begin{array}{l}\text { Circular gallery in bricks } \\
\left(R=1550 \mathrm{~mm} ; S=4.6 \mathrm{~m}^{2}\right)\end{array}$} & 200 & 34.152 & 0.2500 & 2.750 & \multirow{2}{*}{4} \\
\hline & 400 & 62.503 & 0.25012 & 2.750 & \\
\hline \multirow{2}{*}{$\begin{array}{l}\text { Circular gallery in bricks } \\
\left(R=2000 \mathrm{~mm} ; S=12.56 \mathrm{~m}^{2}\right)\end{array}$} & 200 & 37.046 & 0.4200 & 4.620 & \multirow{2}{*}{4} \\
\hline & 400 & 48.261 & 0.4200 & 4.620 & \\
\hline \multirow{2}{*}{$\begin{array}{l}\text { Vaulted gallery with straight } \\
\text { walls }\left(S=4.2 \mathrm{~m}^{2}\right)\end{array}$} & 200 & 29.972 & 0.2015 & 2.220 & \multirow{2}{*}{4} \\
\hline & 400 & 36.249 & 0.2020 & 2.222 & \\
\hline
\end{tabular}

It should be noted that the stiffness matrix is given by the matrix of matrixes corresponding to the elastic or elastic-plastic stiffness, in function of the time $(t)$ in which we will place the support - system mounting.

The normal pressure on the support system or reaction of the support system, by applying the finite element method, will be:

$$
\begin{aligned}
& p_{i}=-\left(F_{i} \cos \alpha_{i+1}+F_{i} \sin \alpha_{i+1}\right) ; \\
& i=(N, N+1, N+2, \ldots N+n),
\end{aligned}
$$

where:

$\alpha_{i}$ - the angle which a finite element forms with the $x$ axis, that is determined based on the coordinates of the knots;

$F_{i}$ - the vectorial components of the vector $\left\{F^{S-M}\right\}$, namely the stresses on the support system.

Based on the analysis of the proposed algorithm, it is found that it does not differs from that of determining the state of tension only by modifying the data used, the increase in the number of finite elements and a number of restrictions to be imposed depending on the type of support used and of course, the deformation domain of the considered the rock.

This algorithm was applied to study two cases:

- the case of constant bearing capacity, $p_{i}=$ constant;

- the case of increasing bearing capacity, $p_{i}=\lambda \cdot u_{r}(t)$, where: $\lambda$-support system stiffness; $u_{r}(t)$ - displacement with time.

\section{RESULTS AND DISCUSSION}

The results obtained by the numerical calculation, according to the proposed algorithm are presented graphically in Figures $2-6$.

Analyzing the obtained results it is found that with the execution of the underground working tension state changes, modification reflected by the occurrence of stress concentrations that jeopardize more or less the stability of mining work, through the pressure it creates. (a)

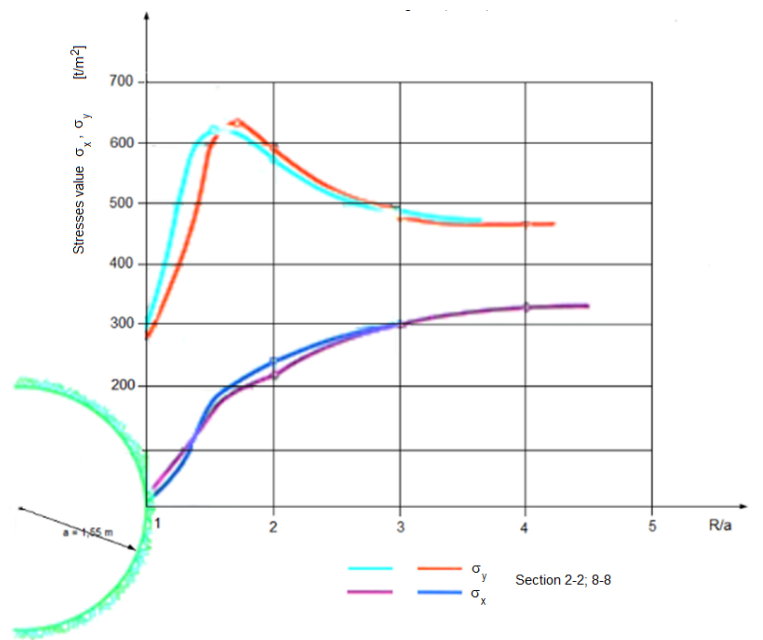

(b)

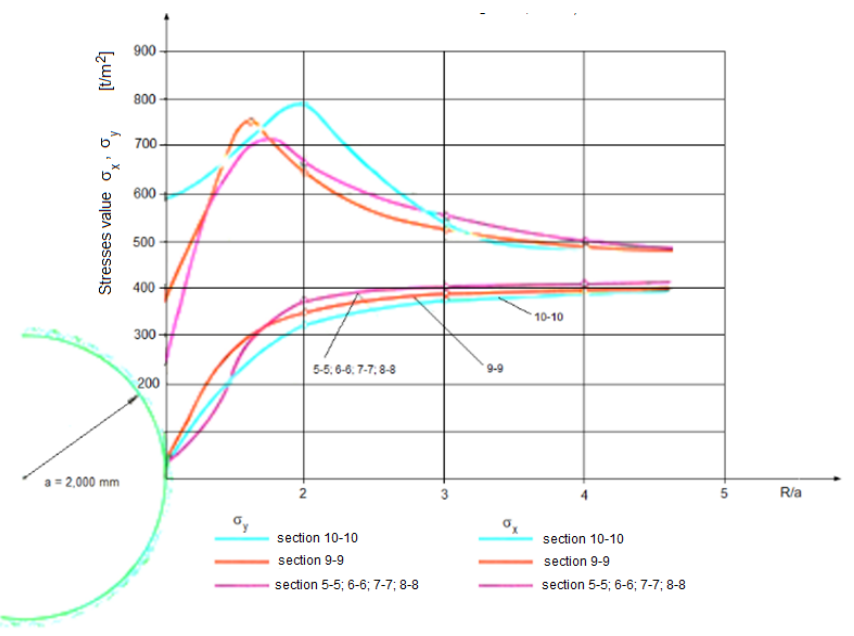

Figure 2. Stress variation around the mining work: (a) $D=3100 \mathrm{~mm}$; (b) $D=4000 \mathrm{~mm}$ 
(a)

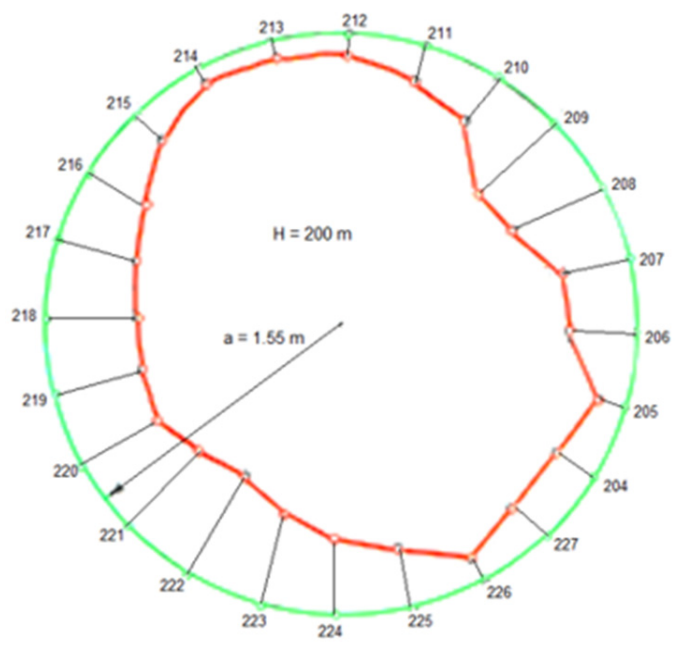

mining work contour before deformation (b)

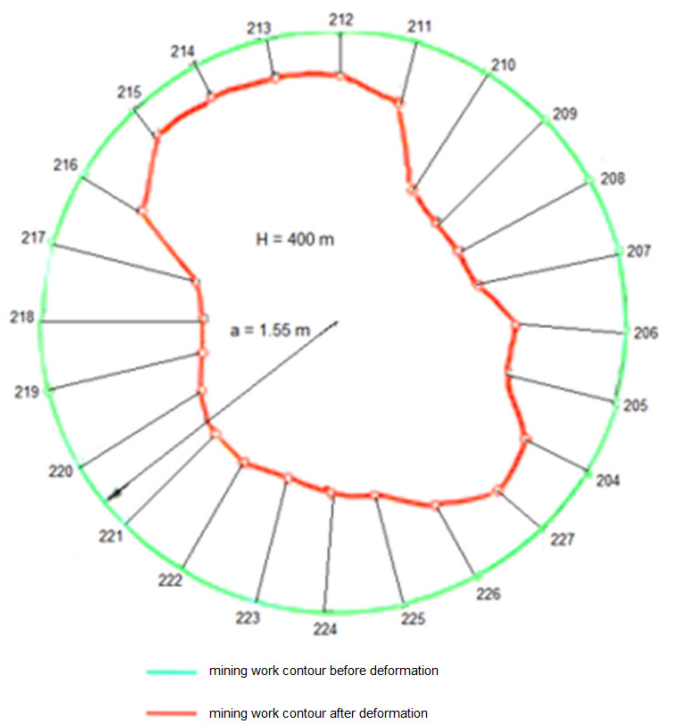

Figure 3. Epure of radial movements: (a) $\mathrm{H}=200 \mathrm{~m}$; (b) $\mathrm{H}=400 \mathrm{~m}$

(a)

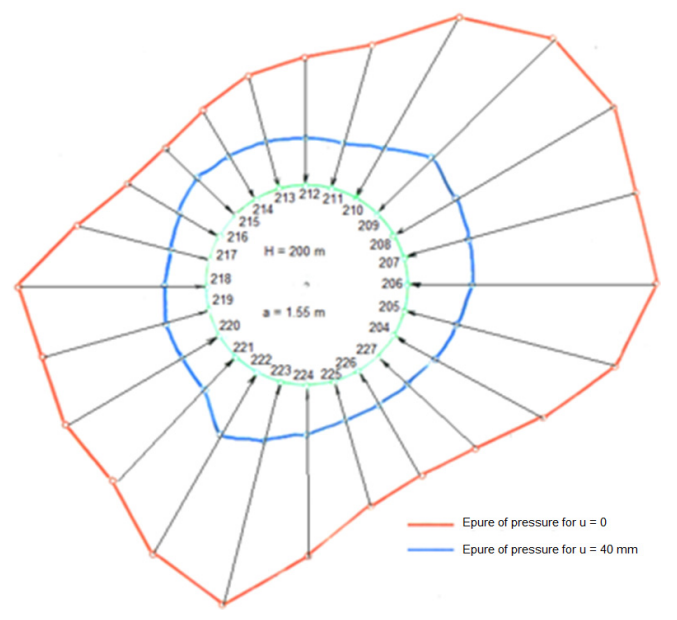

(b)

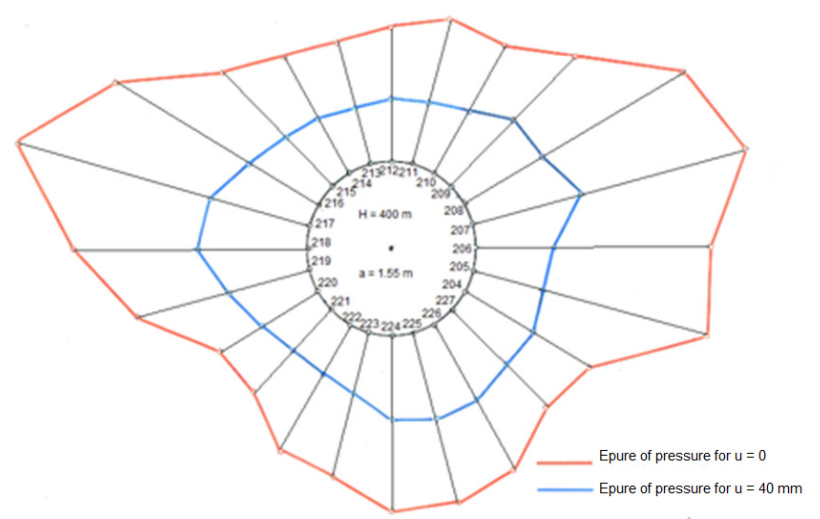

Figure 4. Epure of pressure: (a) $\mathrm{H}=200 \mathrm{~m}$; (b) $\mathrm{H}=400 \mathrm{~m}$

(a)

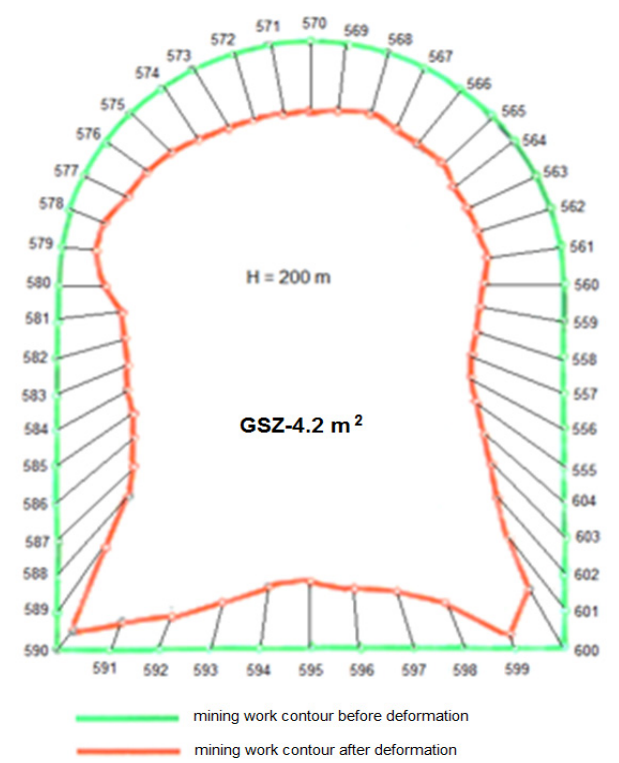

(b)

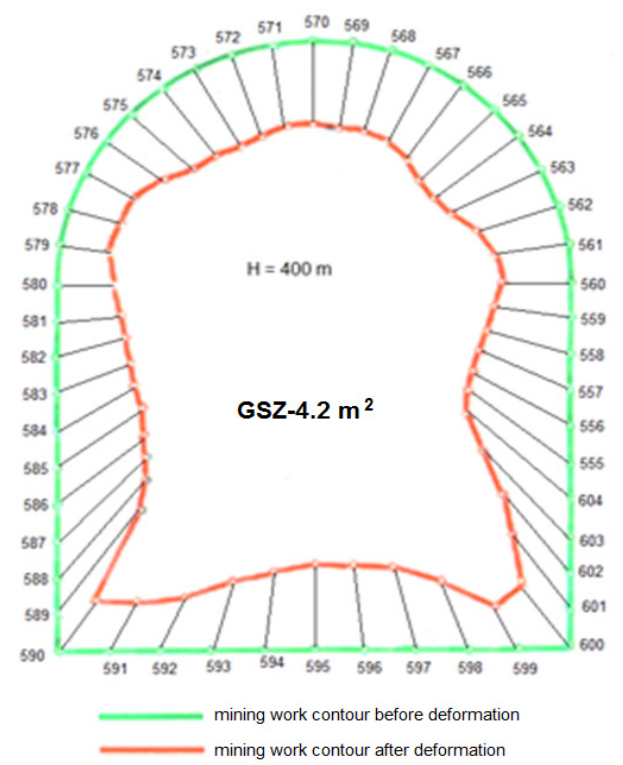

Figure 5. Epure of radial movements produces in mine work: (a) $\mathrm{H}=200 \mathrm{~m}$; (b) $\mathrm{H}=400 \mathrm{~m}$ 
(a)

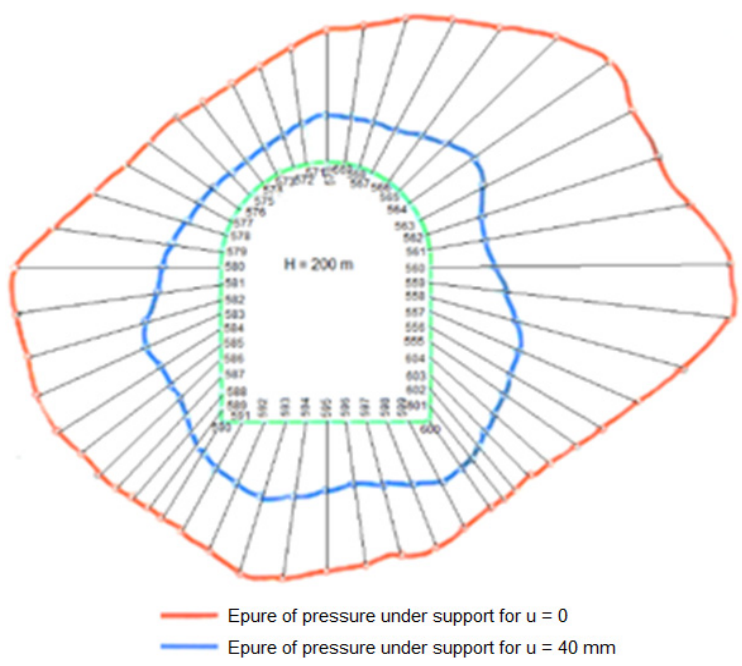

(b)

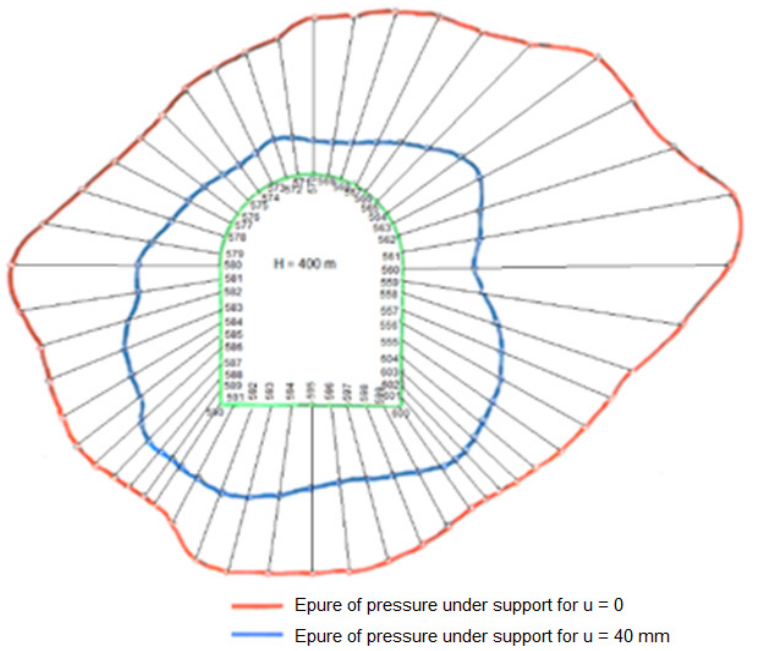

Figure 6. Epure of pressure for the mining work GSZ-4.2 $\mathrm{m}^{2}$ : (a) $\mathrm{H}=200 \mathrm{~m}$; (b) $\mathrm{H}=400 \mathrm{~m}$

In our case, the case of andesitic rocks strongly metamorphosed hydrothermally tensions occurs, which causes mine pressure for which directing the stress can only be achieved by creating opportunities for relaxation of the rock - support system, where after relaxation the tangential stresses are decreasing in value outline the work contour, their maximum moving at a distance equal to the radius of non-elastic area, then decreasing towards the stress value in the undisturbed massif (Fig. 2).

Radial stress values on the contour can not be considered null; there is highlighted a variation in their value with the cross-section of the mine working and with the depth of the location thereof, namely for an increase of these two parameters, radial tensions are increasing from the contour to the massif, reaching lower and lower values compared to the tension state in the massif, which explains the worsening of workings stability with increasing cross section and depth.

The movements that occur develops a certain free deformation of the rocks on the contour, the limit size of which is depending on the size of the cross section of mining work, their shape, depth, massif properties, the time and the type of support used.

Time has an indirect influence on the size of movements, in the sense with time the rock changes its characteristics, losing its strength and being prone to increasingly large displacements. The amount of displacement is closely related to the reaction of the support due to the bi-univocal dependence that occurs between these two dimensions and time. The phenomenon of relaxation accomplished by radial movement promotes the stability of horizontal mine workings but only up to a certain value $\left(u_{r} \leq u_{p l}\right)$, after which it can worsen the cooperation rock - support system, thus jeopardizing the stability.

The pressure regime created by executing horizontal mine workings in andesite rocks highly metamorphosed occurs irregularly. The shape of the diagram of the arrangement of pressure distribution on the perimeter of the main horizontal mine workings is a lemniscate and this shape is not accidental, since it was found and confirmed by the observations in situ which showed destruction of the wall either completely or partially on the portions where it is concluded that there is internal stress created by the uneven distribution of mine pressure. The workings carried out in the considered conditions are characterized by very high pressure on the side and from the floor (Fig. 2).

The pressure regime was determined by placing a restriction, namely: limiting the radial movements of the contour of the mine working by thee classical monolithic concrete, support mounted immediately after cutting, and regarded as having a load constant capacity, modulus of elasticity of this support is much higher than of the rock, which allowed to admit that the stiffness $\lambda \rightarrow \infty$, corresponding for a displacement on the contour $u_{r}=0$.

The pressure regime determined through the management of rock - supporting system interaction with the use of an increasing load capacity was mathematically modelled through the restriction $u_{r}=40 \mathrm{~mm}$.

In this case, around the mine working it is formed a relaxation area and there is noticed a change of pressure regime and even some uniformity of it. Determined maximum and minimum pressures under rock - support system interaction at different depths and different mining shaped and sized mine workings are shown in Table 2.

To assess the stability of underground mine workings, the methodology developed and applied in this case is based on the principle of conformity and safety level assessment, considering the requirements imposed in this case. The method that we proposed is based on the definition of conformity in the field of safety and health at work (Moraru \& Băbuț, 2013; Băbuţ \& Moraru, 2014), so we established a mathematical model for assessing the stability of underground workings to take into account factors that influence the stability.

Without going into details here on the description of the proposed method, we mention only that were considered the main factors which are indicators of quantitative assessment. Each of these factors were taken as an indication de have associated weighting coefficients having values $1,2,3,4$ or 5 depending on the importance and influence on the stability. Once the assessment of all factors done, there were determined: the level of conformity (NC), the safety level (NS) and the degree of non-conformity (GC) based on the score obtained (PO) and the maximum score (PM) (Table 3). 
Table 2. Mine pressure values in the context of rock - support interaction

\begin{tabular}{|c|c|c|c|c|c|c|c|c|}
\hline \multirow{5}{*}{ Mine working type and shape } & \multicolumn{8}{|c|}{ Mine working's location depth } \\
\hline & \multicolumn{4}{|c|}{$H=200 \mathrm{~m}$} & \multicolumn{4}{|c|}{$H=400 \mathrm{~m}$} \\
\hline & \multicolumn{8}{|c|}{ Mine pressure, $\mathrm{daN} / \mathrm{cm}^{2}$} \\
\hline & \multicolumn{2}{|c|}{$u=0$} & \multicolumn{2}{|c|}{$u=40$} & \multicolumn{2}{|c|}{$u=0$} & \multicolumn{2}{|c|}{$u=40$} \\
\hline & $p_{\max }$ & $p_{\text {min }}$ & $p_{\max }$ & $p_{\min }$ & $p_{\max }$ & $p_{\min }$ & $p_{\max }$ & $p_{\min }$ \\
\hline Brick-supported gallery, $S=4.2 \mathrm{~m}^{2}$ & 10.4 & 4.2 & 0.328 & 0.159 & 14.8 & 5.5 & 0.56 & 0.29 \\
\hline $\begin{array}{l}\text { Brick-supported gallery, straight } \\
\text { walls vaulted roof, } R=1380 \mathrm{~mm}\end{array}$ & 11.756 & 3.906 & 0.379 & 0.118 & 14.908 & 5.310 & 1.245 & 0.321 \\
\hline $\begin{array}{l}\text { Brick-supported gallery, } \\
\text { circular profile, } R=2000 \mathrm{~mm}\end{array}$ & 11.8500 & 5.1506 & 0.68 & 0.25 & 20.45 & 8.32 & 1.3604 & 0.3400 \\
\hline
\end{tabular}

Table 3. Proposed methodology for underground working stability assessment

\begin{tabular}{|c|c|c|c|c|c|c|c|}
\hline \multirow{4}{*}{$\begin{array}{c}\text { Crt. } \\
\text { no }\end{array}$} & \multirow{4}{*}{ Indicators (main influence factor) } & \multicolumn{5}{|c|}{ Stability class } & \multirow{4}{*}{$\begin{array}{l}\text { Weighting } \\
\text { factor }\end{array}$} \\
\hline & & A & $\mathrm{B}$ & $\mathrm{C}$ & $\mathrm{D}$ & $\mathrm{E}$ & \\
\hline & & \multicolumn{5}{|c|}{ Points rating } & \\
\hline & & 5 & 4 & 3 & 2 & 1 & \\
\hline 1 & Support system stiffness, $\%$ & & $x$ & & & & 4 \\
\hline 2 & Stress state after working's execution, $\%$ & & & $x$ & & & 3 \\
\hline 3 & Rock massif’s characteristics, $\%$ & & & & $x$ & & 2 \\
\hline 4 & Time, $\%$ & & & $x$ & & & 3 \\
\hline 5 & Mine working's geometry, \% & & & $x$ & & & 3 \\
\hline 6 & Mine working's location depth, \% & & & $x$ & & & 3 \\
\hline \multicolumn{2}{|c|}{ Total points assigned to the indicators rated 5} & & & & & A & 5 \\
\hline \multicolumn{2}{|c|}{ Total points assigned to the indicators rated 4} & & & & & $\mathrm{~B}$ & 4 \\
\hline \multicolumn{2}{|c|}{ Total points assigned to the indicators rated 3} & & & & & $\mathrm{C}$ & 9 \\
\hline \multicolumn{2}{|c|}{ Total points assigned to the indicators rated 2} & & & & & $\mathrm{D}$ & 2 \\
\hline \multicolumn{2}{|c|}{ Total points assigned to the indicators rated 1} & & & & & $\mathrm{E}$ & 0 \\
\hline \multicolumn{2}{|c|}{ Number of applicable indicators weighted by 5} & & & & & $\mathrm{f}$ & 3 \\
\hline \multicolumn{2}{|c|}{ Number of applicable indicators weighted by 4} & & & & & g & 2 \\
\hline \multicolumn{2}{|c|}{ Number of applicable indicators weighted by 3} & & & & & $\mathrm{~h}$ & 1 \\
\hline \multicolumn{2}{|c|}{ Number of applicable indicators weighted by 2} & & & & & $\mathrm{i}$ & 0 \\
\hline \multicolumn{2}{|c|}{ Number of applicable indicators weighted by 1} & & & & & $\mathrm{j}$ & 0 \\
\hline \multicolumn{2}{|c|}{ Obtained points: $\mathrm{PO}=\mathrm{A}+\mathrm{B}+\mathrm{C}+\mathrm{D}+\mathrm{E}$} & & & & $\mathrm{PO}$ & & 20 \\
\hline \multicolumn{2}{|c|}{ Maximum points: $P M=5(f+g+h+i+j)$} & & & & PM & & 30 \\
\hline \multicolumn{2}{|c|}{ Conformity level, $\%$} & & & & $\mathrm{NC}$ & & 66.6667 \\
\hline \multicolumn{2}{|c|}{ Obtained Points: $\mathrm{PO}^{\prime}=5 \mathrm{~A}+4 \mathrm{~B}+3 \mathrm{C}+2 \mathrm{D}+\mathrm{E}$} & & & & PO' & & 72 \\
\hline \multicolumn{2}{|c|}{ Maximum Points: $\mathrm{PM}^{\prime}=5(5 \mathrm{f}+4 \mathrm{~g}+3 \mathrm{~h}+2 \mathrm{i}+\mathrm{j})$} & & & & PM' & & 130 \\
\hline \multicolumn{2}{|c|}{ Safety level, \% } & & & & NS & & 55.3846 \\
\hline \multicolumn{2}{|c|}{ Unconformity degree, $\%$} & & & & GC & & 33.3333 \\
\hline
\end{tabular}

The value of the level of safety which is also equivalent to the stability of the considered mine workings show that they have a low stability (55.3846\%), which is consistent with the results obtained by the numerical method, and observations carried out. Depending on NS value, the correspondence to the stability class of underground mine workings is shown in Table 4.

Table 4. Correspondence between the safety criterion NS and the stability class of mine workings

\begin{tabular}{cc}
\hline Safety level, $\%$ & Mine workings stability class \\
\hline $91-100$ (very high) & Very high stability \\
$81-90$ (high) & High stability \\
$61-80$ (average) & Average stability \\
$40-60$ (low) & Low stability (instability) \\
$<40$ (very low) & Very low stability (total instability) \\
\hline
\end{tabular}

\section{CONCLUSIONS}

Given the nature, intensity and direction of manifestation of tensions and displacements of rocks on the contour of the studied mine workings, considering the construction of support systems employed on the one hand, and the pressure values obtained in this context on the other hand, it resulted that between these two main factors rock support system, there is no a rational congruence, which makes it impossible to find an economic and technical solutions to achieve in this situation stability of mine workings developed in strongly metamorphosed andesites.

The values relating to the pressure regime considered in the two limit cases shows that the distribution and size of stresses on the support system in the case of the elastic-plastic model depends mainly on the support's stiffness, the stresses that occur after execution of the underground working, time, massif's characteristics, the geometric characteristics of mine working and depth.

The strain state, the rigidity of the support and time are parameters with great influence as they the behavior of interaction rock - support must be known in all states, including the interim ones, especially to the final support which is non-deformable, stable and that it may withstand should not be stressed outside the elastic range.

Therefore, the surrounding rock must relax so that the inelastic area to reach at a certain time a certain radius. Consequently, in strongly metamorphosed andesite rock 
type is not recommended a rigid concrete support, but a support with a gradually increasing load capacity, a compressible support up to a point, then working stiff.

Rational is the steady-state of horizontal mine workings to be assessed using methods of hereditary creep simultaneously examining the two temporal phenomena which are overlapping, however, namely: the deformation of the rock depending on the support stiffness and decrease process of the rock's resistance, characterized by long time strength function (in our case the Abel nucleus).

In the case of analyzed rocks, andesitic type strongly metamorphosed, there is registered a progressive decrease in their resistance, being characterized in terms of pressure regime through a system of unstable, vulnerable equilibrium.

The decrease in resistance occurs primarily in the directions of determinative anisotropy, generalizing with the increased displacements around the contour of the surrounding rock mass, resulting in a change of elastic constants in time.

In the cases analyzed and presented, where the process of deformation of rocks has a continuous character over a long period of time, the support systems should have also a proper bearing capacity, and a release rate able to manage and standardize how to overtake the charges. For these reasons, we recommend that in such circumstances the need for some types of combined support systems to be considered.

\section{ACKNOWLEDGEMENTS}

This work was developed from a theoretical and experimental study on the stability analysis of underground workings located in strongly metamorphosed andesite and determination of mine pressure in the context of rock - support system interaction. We thank to our colleague dr. Gabriel Băbuţ for his assistance and support in developing the mathematical model based on the principle of proper conformity and safety level, according to the main factors that influence the stability of underground workings. We would also like to show our gratitude to the University of Petrosani which provided the necessary equipment to perform all laboratory tests in prior experimental researches leading to the results synthesized in this article.

\section{REFERENCES}

Baud, P., Zhu, W., \& Wong, T. (2000). Failure mode and weakening effect of water on sandstone. Journal of Geophysical Research: Solid Earth, 105(B7), 16371-16389. https://doi.org/10.1029/2000jb900087

Blake, W. (1966). Application of the finite element method of analysis in solving boundary value problems in rock me- chanics. International Journal of Rock Mechanics and Mining Sciences \& Geomechanics Abstracts, 3(3), 169-180. https://doi.org/10.1016/0148-9062(66)90021-0

Brady, B.G.H., \& Brown, E.T. (1985). Rock mechanics for underground mining. London, United Kingdom: Georges Allen \& Unwin.

Băbuţ, G.B., \& Moraru, R.I. (2014). Auditarea în domeniul securităţii şi sănătăţii în muncă: Îndrumător pentru aplicaţii practice şi proiecte. Petroşani, Romania: Editura Universitas.

Clough, R.W. (1965). The finite element method in structural mechanics in stress analysis. New York, United States: John Wiley.

De Kerckhove, P., \& Rollier, J. (2003). Développement de méthodes de calcul en ligne dans le cadre d'un didacticiel de tunnel. Paris, France: Travail de fin d'étude (UCL).

Fomychov, V., Pochepov, V., Fomychova, L., \& Lapko, V. (2017). Computational model for evaluating the state of geomechanical systems during computing experiments. Mining of Mineral Deposits, 11(1), 100-105. https://oi.org/10.15407/mining11.01.100

Lemaitre, J., \& Chaboche, J.L. (1988). Mécanique des matériaux solides. Paris, France: Dunod.

Masuda, K. (2001). Effects of water on rock strength in a brittle regime. Journal of Structural Geology, 23(11), 1653-1657. https://doi.org/10.1016/s0191-8141(01)00022-0

Moraru, R.I., \& Băbuţ, G.B. (2013). Evaluarea riscurilor profesionale: Îndrumător pentru aplicaţii practice şi proiecte. Petroşani, Romania: Editura Universitas.

Obert, L., \& Duvall, W.L. (1967). Rock mechanics and design of structures in rock. New York, United States: John Wiley.

Reyes, F.S., \& Deer, D.U. (1966). Elastic-plastic analysis of underground opening by finite element method. Proceeding of the First Congress of International Society of Rock Mechanics, (2), 1-7.

Richter, R. (1968). Plastische greztief. Budapest, Hungary: Banyaszati Lapok.

Stan-Kłeczek, I., \& Idziak, A.F. (2008). Anisotropy of elastic properties of rock mass induced by cracks. Acta Geodynamica and Geomaterialia, 5(2(150)), 153-159.

Stolle, D.F.E. (1989). Vâscoelasticity and plasticity numerical stability revisited. Proceedings of the $3^{\text {rd }}$ International Symposium on Numerical Models in Geomechanics. Niagara Falls: Elserer Applied Sciences.

Toderaş, M. (2014). Rock, Soils and Underground Construction Mechanics. Petroşani, Romania: Universitas Publishing House.

Toderaş, M., Moraru, R.I., \& Popescu-Stelea, M. (2015). Underground mine workings convergence dependence on operation time and location depth. Journal of Mining Science, 51(3), 541-552. https://doi.org/10.1134/s1062739115030163

Toderas, M., \& Moraru, R. (2017). The effect of increasing the water content on rocks characteristics from Şuior, Romania. Mining of Mineral Deposits, 11(3), 1-14. https://doi.org/10.15407/mining11.03.001

Toderaş, M., \& Danciu, C. (2017). Stability analysis methods of underground mining works. Saarbrücken, Germany: Lambert Academic Publishing.

\section{РОЗРАХУНОК ГІРСЬКОГО ТИСКУ МЕТОДОМ КІНЦЕВИХ ЕЛЕМЕНТІВ З УРАХУВАННЯМ ВЗАСМОДІЇ У СИСТЕМІ ПОРОДНИЙ МАСИВ - КРІПЛЕННЯ}

\section{М. Тодерас, Р. Морару, К. Данчу}

Мета. Аналіз стійкості підземних гірничих виробок, пройдених у сильно метаморфізованому андезиті, за допомогою чисельних методів моделювання. Визначити характер впливу гірського тиску з урахуванням взаємодії у системі “породний масив - кріплення", впливу неоднорідних напружень, анізотропії порід і часу.

Методика. Чисельний метод кінцевих елементів використовувався для розрахунку радіального зміщення різних напружень і побудови епюри напружень для аналізованої шахти. У якості критерія міцності прийнята 
гіпотеза Кулона-Мора, узагальнена Друкером-Прагером відповідно до припущень Рейеса. Стійкість підземних виробок оцінювалася за допомогою математичної моделі, яка була створена на основі принципу необхідного рівня конформності та безпеки, відповідно до основних факторів, що впливають на стійкість підземних виробок.

Результати. Результати, отримані у ході спостережень і чисельними методами, свідчать про низький рівень стійкості аналізованих підземних виробок. Встановлено, що зі збільшенням поперечного перерізу виробки $\mathrm{i}$ глибини іiі залягання радіальні напруження зростають від контуру до масиву, досягаючи більш низьких значень у порівнянні з напруженим станом в масиві, чим і пояснюється погіршення стійкості виробок. Визначено фактори, за якими оцінена стійкість виробки: рівень відповідності (NC), рівень безпеки (NS) і ступінь невідповідності (GC) на основі отриманої оцінки (PO) та максимальної оцінки (РM). Рекомендовано використовувати у сильно метаморфізованому андезитовому типі порід не жорстке бетонне кріплення, а кріплення з вантажонесучою здатністю, що поступово збільшується.

Наукова новизна. Розкрито механізм деформування системи “масив - кріплення” у сильно метаморфізованих андезитових породах. На основі нового математичного підходу до оцінки стійкості виробок встановлено відповідність між критерієм безпеки NS і класом стійкості гірничих виробок.

Практична значимість. Результати дослідження сприятимуть поліпшенню стійкості гірничих виробок i значно підвищать рівень виробничої безпеки протягом всього періоду їх експлуатації.

Ключові слова: стійкість, гірський тиск, кріплення, метод кінцевих елементів, рівень конформності, безпека

\section{РАСЧЕТ ГОРНОГО ДАВЛЕНИЯ МЕТОДОМ КОНЕЧНЫХ ЭЛЕМЕНТОВ С УЧЕТОМ ВЗАИМОДЕЙСТВИЯ В СИСТЕМЕ ПОРОДНЫЙ МАССИВ - КРЕПЬ}

\section{М. Тодерас, Р. Морару, К. Данчу}

Цель. Анализ устойчивости подземных горных выработок, пройденных в сильно метаморфизованном андезите, с помощью численных методов моделирования. Определить характер влияния горного давления с учетом взаимодействия в системе “породный массив - крепь", влияния неоднородных напряжений, анизотропии пород и времени.

Методика. Численный метод конечных элементов использовался для расчета радиального смещения различных напряжений и построения эпюры напряжений для анализируемой шахты. В качестве критерия прочности принята гипотеза Кулона-Мора, обобщенная Друкером-Прагером в соответствии с предположениями Рейеса. Устойчивость подземных выработок оценивалась при помощи математической модели, которая была создана на основе принципа необходимого уровня конформности и безопасности, в соответствии с основными факторами, влияющими на устойчивость подземных выработок.

Результаты. Результаты, полученные в ходе наблюдений и численными методами, свидетельствуют о низком уровне устойчивости анализируемых подземных выработок. Установлено, что с увеличением поперечного сечения выработки и глубины ее заложения радиальные напряжения возрастают от контура к массиву, достигая более низких значений по сравнению с напряженным состоянием в массиве, чем и объясняется ухудшение устойчивости выработок. Определены факторы, по которым оценена устойчивость выработки: уровень соответствия (NC), уровень безопасности (NS) и степень несоответствия (GC) на основе полученной оценки (PO) и максимальной оценки (PM). Рекомендовано использовать в сильно метаморфизованном андезитовом типе пород не жесткую бетонную крепь, а крепь с постепенно увеличивающейся грузонесущей способностью.

Научная новизна. Раскрыт механизм деформирования системы “массив - крепь” в сильно метаморфизированных андезитовых породах. На основе нового математического подхода к оценке устойчивости выработок установлено соответствие между критерием безопасности NS и классом устойчивости горных выработок.

Практическая значимость. Результаты исследования будут способствовать улучшению устойчивости горных выработок и значительно повысят уровень производственной безопасности в течение всего периода их эксплуатации.

Ключевые слова: устойчивость, горное давление, крепь, метод конечных элементов, уровень конформности, безопасность

\section{ARTICLE INFO}

Received: 19 November 2018

Accepted: 25 January 2019

Available online: 30 January 2019

\section{ABOUT AUTHORS}

Mihaela Toderas, Doctor of Philosophy, Professor of the Mining Engineering, Surveying and Civil Engineering Department, University of Petrosani, 20 University St, 332006, Petrosani, Romania. E-mail: toderașmihaela@yahoo.com

Roland Moraru, Doctor of Philosophy, Professor of the Management and Industrial Engineering Department, University of Petrosani, 20 University St, 332006, Petrosani, Romania. E-mail: roland moraru@yahoo.com

Ciprian Danciu, Doctor of Philosophy, Lecturer of the Mining Engineering, Surveying and Civil Engineering Department, University of Petrosani, 20 University St, 332006, Petrosani, Romania. E-mail: danciu_ciprian@yahoo.com 